\title{
Phakomatosis Pigmentovascularis
}

\author{
Dirk Van Gysel, M.D., ${ }^{*} \dagger$ Arnold P. Oranje, M.D., Ph.D., ${ }^{*}$ Hans Stroink, M.D., $\ddagger$ and \\ Huibert J. Simonsz, M.D.§
}

* Subdivisions of Pediatric Dermatology, $¥$ Pediatric Neurology, and §Ophthalmology, Sophia Children’s Hospital/University Hospital, The Netherlands, Rotterdam, and †Subdivision of Pediatric Dermatology, O.L.V. Hospital, Aalst, Belgium

\begin{abstract}
We report a patient with phakomatosis pigmentovascularis $\mathrm{Ilb}$ and numerous iris hamartomas. Phakomatosis pigmentovascularis $\mathrm{llb}$ is characterized by the simultaneous occurrence of a nevus flammeus, a mongolian spot, and sometimes a nevus anemicus in the same individual, with systemic involvement. To our knowledge, the association with multiple iris hamartomas has been reported only once. This second patient suggests that the association might be more common. Additional reports will indicate if such an association is more frequent than is now assumed.
\end{abstract}

Phakomatosis pigmentovascularis is a syndrome characterized by the simultaneous occurrence of a pigmented nevus and a vascular nevus in the same individual. Further classification within the syndrome is based on the type of pigmented nevus. We report a patient with all the typical findings of phakomatosis pigmentovascularis type IIb.

\section{CASE REPORT}

A 5-year-old girl was referred to the Pediatric Dermatology Unit of the Sophia Children's Hospital, Rotterdam, because of blue macules and extensive, blanchable, erythematous areas on the skin. In addition, blue macules were present in her eyes. She never had seizures and her mental development was normal.

Examination showed an extensive nevus flammeus on the trunk and lower limbs. A large mongolian spot was noted on the left thorax wall. A nevus anemicus adjoining the nevus flammeus was present on the neck (Fig. 1). Large blue macules were seen intrasclerally on the bulbar conjunctiva of both eyes (Fig. 2). No other abnormalities were observed on general physical and neurologic examinations. During the first years of life the girl's electroencephalograms showed slight asymmetry of the background pattern, but no epileptic discharges. A contrast-enhanced computerized tomographic scan of the brain was normal. Bilateral iris hamartomas were observed on ophthalmologic slit lamp examination (Fig. 3).

\section{DISCUSSION}

Phakomatosis pigmentovascularis syndrome is characterized by the simultaneous occurrence of a pigmented nevus and a vascular nevus. A nevus flammeus is always present and frequently extends bilaterally to the face, skull, trunk, and limbs. Histologic examination shows dilated capillaries in the superficial dermis. Classification into four categories $(1,2)$ is based on the type of coexistent pigmented nevus (Table 1).

The cutaneous pigmentary abnormalities may

Address correspondence to Arnold P. Oranje, M.D., Subdivision of Pediatric Dermatology, Sophia Children's Hospital, Dr. Molewaterplein 60, 3015 GJ Rotterdam, The Netherlands. 


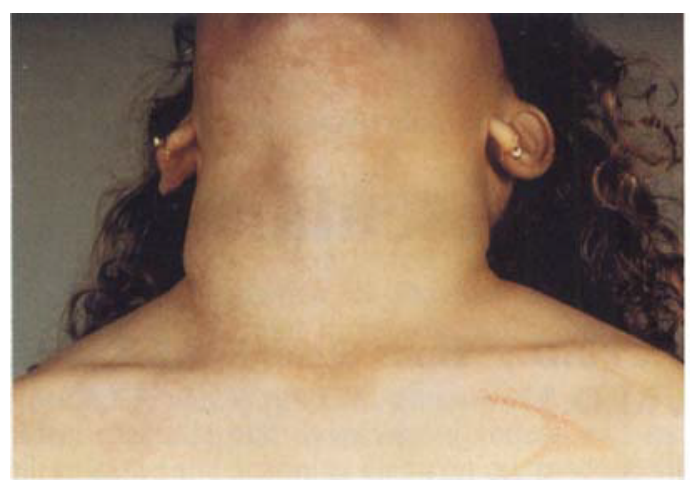

Figure 1. Nevus anemicus adjoining the nevus flammeus on the neck.

consist of slate-gray skin pigmentation or zones of blue skin coloration that lead one to think of an aberrant mongolian spot, nevus of Ito, or nevus of Ota. Other frequently occurring skin lesions are nevus anemicus and nevus spilus. Histologic examination of an abnormal pigmentation zone shows dermal melanocytosis without an increase in the number of epidermal melanocytes. Visible abnormalities of the eyes include blue macules or a more diffuse blue-gray coloration of the sclerae (3).

Various other associated abnormalities have also been described. The most frequent are psychomotor retardation, epilepsy, intracranial calcifications, and cerebral atrophy (3). The patient reported here is typical of phakomatosis pigmentovascularis type IIb. The presence of numerous iris hamartomas in this girl is especially interesting because such an association has been reported only once before (4).

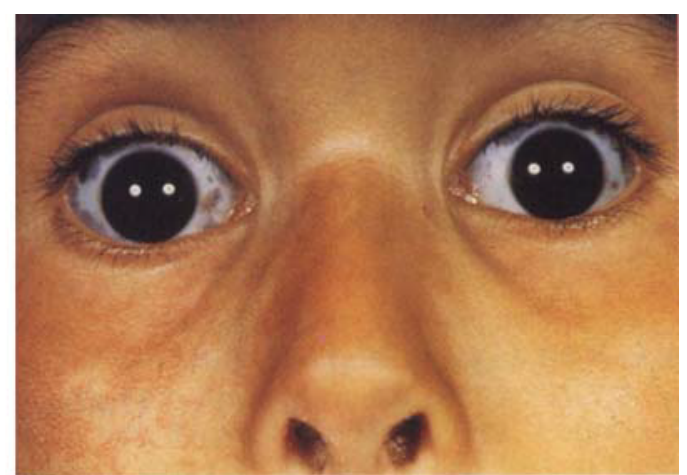

Figure 2. Blue macules on the bulbar conjunctivae of both eyes.

TABLE 1. Classification of

Phakomatosis Pigmentovascularis

\begin{aligned} & \hline Type Characteristics \\ & \hline I $a, b \begin{array}{l}\text { Nevus flammeus and nevus pigmentosus et } \\ \text { verrucosus }\end{array} \\ &$ II a, b $\begin{array}{l}\text { Nevus flammeus, mongolian spot } \pm \text { nevus } \\ \text { anemicus }\end{array} \\ &$ III $\mathrm{a}, \mathrm{b} \begin{array}{l}\text { Nevus flammeus, nevus spilus } \pm \text { nevus } \\ \text { anemicus }\end{array} \\ &$ IV a, b $\begin{array}{c}\text { Nevus flammeus, mongolian spot, nevus } \\ \text { spilus } \pm \text { nevus anemicus }\end{array} \\ &$\hline\end{aligned}

$a=$ limited to the skin; $b=$ cutaneous and systemic.

Differential diagnostic considerations include Sturge-Weber syndrome, mongolian spot, nevus of Ota, and nevus of Ito. Sturge-Weber syndrome can be differentiated from phakomatosis pigmentovascularis by the absence of cutaneous and ocular melanosis, and the different characteristics of the nevus

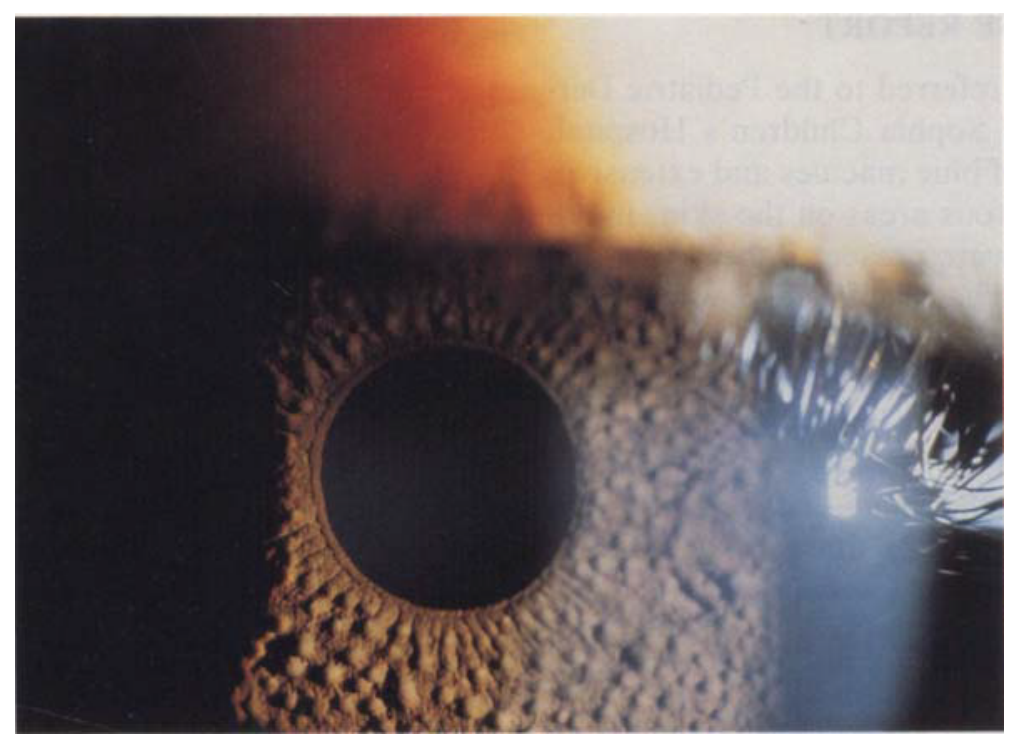

Figure 3. Iris hamartomas visible on slit lamp examination. 
flammeus (mostly craniofacial and unilateral, and histologically uncharacteristic). Mongolian spot, nevus of Ota, and nevus of Ito can be distinguished easily from phakomatosis pigmentovascularis by the absence of a nevus flammeus and by their typical localization. The predilection site of a mongolian spot is the skin over the sacrum and distal part of the back, but other aberrant localizations are possible. A nevus of Ota occurs unilaterally in the distribution of the first and second branches of the trigeminal nerve, and is associated with a blackbrown pigmentation in the ocular region. A nevus of Ito is localized to the shoulder and upper chest region. In addition, histologic examination shows an increased number of epidermal melanocytes in the nevus of Ito.

The etiology of phakomatosis pigmentovascularis remains unknown. Happle $(5,6)$ postulated that this syndrome arises as a result of a twin-spot phenomenon: at a gene locus controlling cutaneous vascularization, patients carry one allele responsible for increased vasodilation, whereas the corresponding allele accounts for increased vasoconstriction. The two alleles balance each other, resulting in a normal vascular tone. Somatic recombination may give rise to two different homozygous cells, being the stem cells of the two different vascular nevi. One of these stem cells may have become, in addition, homozygous for a mutation on a neighboring gene locus, giving rise to a pigmentary nevus. Other studies $(7,8)$ point to defects in the construction of neural frame-derived vasomotor nerve cells and melanocytes.

The occurrence of iris hamartomas in a patient with phakomatosis pigmentovascularis IIb has been reported only once. Further investigations will determine if this association is more common than previously thought.

\section{REFERENCES}

1. Hasegawa Y, Yasuhara M. Phacomatosis pigmentovascularis type IVa. Arch Dermatol 1985;121: $651-655$.

2. Libow LT. Phacomatosis pigmentovascularis type IIIb. J Am Acad Dermatol 1993;29:305-307.

3. Ruiz-Maldonado R, Tamayo L, Laterza AM, et al. Phacomatosis pigmentovascularis: a new syndrome? Report of four cases. Pediatr Dermatol 1987;4:189. 196.

4. Gilliam AC, Ragge NK, Perez MI, et al. Phakomatosis pigmentovascularis type IIb with iris mammillations, Arch Dermatol 1993;129:340-343.

5. Happle R, Steijlen PM. Phacomatosis pigmentovascularis gedeutet als ein Phänomen der Zwillingsflecken. Hautarzt 1989;40:721-724.

6. Happle R. Allelic mutations may explain vascular twin nevi. Hum Genet 1991;86:321-322.

7. Kitamura W, Iwai M, Sakamoto K. A case of phacomatosis pigmentovascularis. Rinsho Dermatol 1981; 35:399-405.

8. Smoller BR, Rosen S. Port-wine stains: a disease of altered neural modulation of blood vessels? Arch Dermatol 1986;122:177-179. 